\title{
HONOURING ANTHONY ANGELO'S CONTRIBUTION
}

The Victoria University of Wellington Law Review is proud to celebrate the continuing contribution of Professor A H Angelo to the Law Faculty at Victoria University of Wellington and to this Law Review. Professor Angelo was appointed as a Lecturer on 20 December 1967, and subsequently Senior Lecturer in 1971, Reader in 1976, and Professor in 1986. He served as Dean from 1991 to 1994 and as Deputy Dean from 1999 to 2001. As editors, we believe that this issue of the Law Review commemorates appropriately this special landmark. Tony's career exemplifies loyalty to this University, which he has served in so many academic and administrative capacities. It also typifies the qualities to be expected of a scholar and practitioner, as illustrated by his pioneering work in comparative law in New Zealand, including the creation of the New Zealand Association for Comparative Law, and his consulting functions in many jurisdictions. His attention to detail has benefited this Law Review and the work of so many colleagues and students over the years.

This issue is divided into two main parts. The first includes personal reflections either concerning Tony himself, or on subjects inspired by Tony's career, especially on law reform in smaller jurisdictions. The second part contains pieces by leading scholars from all over the world that reflect different aspects of Tony's own research and service agendas, grouped around themes of "The Pacific" and "Wider Perspectives." All the papers are clearly interlinked. Tony's career has been concerned with the very biggest of ideas: the development and study of large legal systems the common law, the civil law and the Japanese - and at the same time the study of the particular, in Tony's case, even the study of the very small legal systems of Mauritius and the island nations of the Pacific. Some of these contributions show the breadth of his academic and practical expertise beyond domestic and comparative legal developments to major areas of public and private international law.

Tony's career shows something unique about legal scholarship and service in our community. The legal systems of the Pacific, including that of New Zealand, are tiny in comparison to the great legal systems of the United Kingdom or France or Germany, or even that which emerged in Japan. All Pacific people are necessarily concerned with the creation and the maintenance of the rule of law and legal institutions in jurisdictions where the small size creates a significant challenge. Even New Zealand, which by dint of its economy can appear to be a giant amongst the Pacific legal systems, often confronts the realisation that its size prevents it from doing things that can be done in larger nations. New Zealanders have resolved some of the difficulties by maintaining links with larger common law legal systems, including England, Scotland, and other members of the British Commonwealth, such as Canada or Australia. A New Zealand lawyer is always conscious of how to fit foreign models into a different, smaller framework. We are trained early on to identify what might be different about the New Zealand situation and to argue about the applicability of overseas 
developments or institutions to New Zealand. The New Zealand legal system would, one suspects, be somewhat lost without that comparative feel.

Much of Tony Angelo's career has drawn on those necessary skills of the New Zealand lawyer and applied them in jurisdictions which are even more challenged in terms of size and economic wealth than New Zealand. His efforts in Mauritius are recorded in essays by Dr George Barton QC, Sir Ivor Richardson, and Peter McKenzie QC, and his service in the Pacific is described by Alison Quentin-Baxter in the context of a wider article, and in shorter pieces by Andrew Townsend and Sue Farran. As one of Tony's close collaborators over the years, Dr Yves-Louis Sage offers a realistic portrait of the difficulties of the French Polynesian political class in complying with regional and international principles of good governance. Dr Jennifer Corrin examines the continuing difficulties created for small states (mostly in the Pacific) by the failure to patriate the United Kingdom laws by which they may or may not be governed and suggests that there is much to be learnt from Tony's work in Nuie and Tokelau. Fran Wright's piece on the theoretical problems created by the uncertainty of the relevant criminal law in the Pitcairn Island sexual abuse trial shows how problematic law can be on a tiny island. Petra Butler assesses the potential of the European Court of Human Rights' notion of the "margin of appreciation" for dealing with the problem of the diversity of approaches to apply to the question of citizens' rights in the Pacific.

Tony's work with small jurisdictions has not distracted him away from also engaging with the truly big. The reflection by Professor Campbell McLachlan highlights Tony's important role in bringing comparative law to New Zealand and in developing the modern study of the conflict of laws in New Zealand. The contributions by Dr Luke Nottage on translation, Professor Aska on Japanese legal education, Professor Schwenzer on the Convention on the International Sale of Goods, Professor Mario Patrono on 50 years of integration efforts in Europe and Professor BoeleWoelki on international family law in the European Union show the diversity of Tony's interests outside the Pacific. The contributions on New Zealand family law by two of the leading New Zealand family law writers, Professors Atkin and Peart, reflect Tony's early scholarly engagement with family property reform in New Zealand and his continuing contribution to the legislative process through the making of extensive parliamentary submissions. Finally, Alberto Costi reflects over the Genocide Convention and the need to look beyond the letter of the law to ensure that legal developments improve human condition, a sentiment that has guided Tony throughout his career.

While this issue honours Tony's professional accomplishments in both research and teaching, we as individuals have also benefited, as have other contributors, from his wisdom and assistance in our own careers. During the time that we have been at the Law Faculty, Tony has exemplified the Victoria tradition that values teaching and service. We, therefore, present this issue to Tony as a token of our respect and affection, and in thanks for his contribution to us personally, our academic community at Victoria, and the legal community in New Zealand, the Pacific and internationally.

Bill Atkin, Petra Butler, Alberto Costi, Geoff McLay Old Government Buildings 